\title{
Effectiveness of participatory monitoring and evaluation on achievement of community-based water projects in Tanzania
}

\author{
S. A. Mgoba' ${ }^{1}$. S. J. Kabote ${ }^{2}$
}

Received: 20 May 2019 / Accepted: 26 June 2020 / Published online: 3 August 2020

(c) The Author(s) 2020

\begin{abstract}
The Government of Tanzania is struggling to implement water projects throughout the country to ensure that $90 \%$ of the population has access to clean and safe drinking water by 2025 . While most of the community-based water projects fail to deliver as expected, participatory monitoring and evaluation (PM\&E), critical for projects' achievement, is at an infancy stage. This article determines effectiveness of PM\&E on achievement of community-based water projects' objectives. The article adopted sequential exploratory research design to collect quantitative and qualitative data. A random sample of 120 water users in the government and NGOs funded projects was involved whereby $53.3 \%$ were women. Focus group discussions (FGDs) and key informant interviews were used to collect qualitative data. SPSS was used to summarize descriptive statistics. Kruskal-Wallis $H$ test was used to compare median differences between the projects, while qualitative data were subjected to content analysis. Overall, $51.7 \%$ of the respondents reported that community-based water projects' objectives were achieved except capacity building. The projects funded by NGOs recorded high achievement relative to the government funded projects. In addition, PM\&E was effective in achieving water projects' objectives. There was a statistically significant difference in responses between low, medium and high effectiveness of PM\&E $(P \leq 0.05)$. Majority reported high effectiveness, more so for NGOs-funded water projects. The article concludes that PM\&E was effective in achieving projects' objectives except capacity building. Therefore, it recommends strengthening of capacity building for the local communities to manage community-based water projects effectively. This is a policy issue that needs serious efforts at all levels of the government.
\end{abstract}

Keywords Participatory · Project management $\cdot$ Water $\cdot$ Projects $\cdot$ Achievement $\cdot$ Tanzania

\section{Introduction}

Water is not only important for life but also for development in general. The use of water for domestic, irrigation, transport, livestock, fishing, wildlife, hydroelectric power generation, environmental flow and recreation justifies the aforementioned argument. Despite importance of water for life and development, Sub-Saharan Africa (SSA) experiences water shortage mainly in rural compared to urban areas. In 2015, for example, $56 \%$ of the population in SSA had access

\section{S. J. Kabote}

sjkabote@sua.ac.tz

1 Department of Policy, Planning and Management, Sokoine University of Agriculture, P.O. Box 3035, Morogoro, Tanzania

2 Department of Development Studies, Sokoine University of Agriculture, P.O. Box 3024, Morogoro, Tanzania to improved water supply in rural areas (World Bank 2018), while $46 \%$ in rural Tanzania accesses drinking water from improved sources (Kamara et al. 2017). This implies that a significant proportion has no access to improved water supply in SSA and Tanzania as well. Water quality for domestic, irrigation and other uses is also a serious concern. While authors in some countries including Kenya have reported good water quality from rivers for irrigation (Chebet et al. 2020), others like Barbieri et al. (2018) reported that $86.7 \%$ of the groundwater was brackish with high concentration of chloride and sodium, and therefore unsafe for domestic use in the Southern Mozambique. In addition, Ricolfi et al. (2020) confirmed, among other toxic elements, presence of mercury and uranium in the groundwater with concentrations exceeding the levels recommended by the World Health Organization (WHO) during wet seasons, in the Limpopo national park. Tanzania is not exceptional; for example, Saria (2012) showed that the water in selected shallow

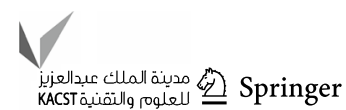


wells in Dar es Salaam city, the biggest city in the country, contained total dissolved solids (TDS) and total hardness outside of the WHO's recommended ranges.

With water shortage and poor quality challenges, SSA has been struggling to ensure that communities have access to improved, clean and safe water supply. The efforts encompass different stakeholders including governments through water programmes and projects. To that effect, achievement of water projects' objectives is considered one of the pressing issues in development because, as reported by Kilonzo and George (2017), most of the community-based water projects in SSA do not deliver as expected. Achievement of water projects is a degree to which water infrastructures provide the services to meet communities' expectations (Radivojevic et al. 2008). Thus, it is a degree to which water objectives are accomplished. The water project objectives considered in this study were capacity building of local communities in water resources management, proper and efficient functionality of water projects, improved water availability and reducing time used particularly by women and girls to fetch water for domestic use.

In a way to enhancing water projects' achievements, the funding of water and sanitation projects increased by $30 \%$ from USD 8.3 billion in 2010 to over USD 10.9 billion in 2012 in SSA (WHO 2012). Nevertheless, the problems attributed to poor achievement of water projects are on the increase. Literature including Kanda et al. (2016) show that poor achievement of water projects' objectives is a common problem in SSA. Most of the water projects fail to achieve the intended objectives in providing communities with clean and safe water, and ensure functioning of water projects' infrastructures as soon as the projects phase out. This is largely contributed by, among other things, inadequate monitoring and evaluation skills among the local communities due to poor capacity building on issues of monitoring and evaluation (United Nations 2015).

Authors like Kabeyi (2019) and George (2020) recognize that participation of the local communities in monitoring and evaluation (M\&E) of development, and by extension, $\mathrm{M} \& \mathrm{E}$ of community-based water projects is fundamental in enhancing achievement of water projects. According to the World Bank (2010), participatory monitoring and evaluation (PM\&E) offers new ways to assess and learn from change that is more inclusive. The importance of PM\&E in ensuring achievement of water projects objectives is acknowledged in many countries. For instance, a study conducted by the World Bank in 2010 in 121 rural water supply projects in 49 countries in African, Asia and Latin America demonstrated that communities' involvement at all stages of a project cycle contribute to effectiveness of the projects.

Tanzania has many water sources when compared with other countries in SSA. The sources include, among others, rivers, lakes, ocean, wetlands, springs, reservoirs and groundwater. The country manages water resource at a basin, catchment, sub-catchment and village levels. The presence of water sources is an opportunity for the water sector and national development. In order to improve access to clean, safe water supply and sanitation, the Government of Tanzania adopted water sector reforms since the 1990s. The country enacted the Water Resources Management Act (WARMA) and Water Supply and Sanitation Act (WASSA) in 2009. In addition, the Water Sector Development Programme (WSDP) that is implemented in three phases of fiveyear each since 2006 is underway. The programme's components include water resources management, rural water supply, urban water supply, and institutional capacity building in the framework of the decentralization approach of the National Water Policy of 2002 (URT 2002, 2014a; WB 2018). Through decentralization approach, water resource is not only managed at a national level but also at local levels by insisting on participatory approaches in water projects that inculcate a sense of community's ownership of the projects and therefore improving projects' achievements and sustainability.

In connection with the efforts done by the government and other development actors, studies conducted in Tanzania on participation in development show that PM\&E is at an infancy stage (Mfinanga and Kaswamila 2014; Kifanyi et al. 2013; Mandara et al. 2013; Masanyiwa et al. 2015). This raises concerns including whether PM\&E is effective in enhancing achievement of water project objectives. Essentially, PM\&E helps, among others, to identify problems at early stages of project implementation and come up with recommendations for improvement (Sherman and Ford 2014). It is also important for guiding local decisionmaking, and promoting implementation of effective interventions and strategies (Kariuki 2014). This study is guided by the following research questions: first, to what extent do community-based water projects achieve their objectives? Secondly, to what extent does PM\&E effective in enhancing achievement of water project objectives?

\section{Methodology}

\section{The study area}

This study was conducted in Chamwino District, Dodoma Region (Fig. 1). Data collection took place between July and December 2018. Chamwino District is located at latitude $6^{\circ} 15^{\prime}$ South, and longitude $35^{\circ} 42^{\prime}$ East. The altitude ranges from 1000 to $1500 \mathrm{~m}$ above sea level. The district has a dry Savannah type of climate, characterized by a long dry season. The minimum temperature is $19^{\circ} \mathrm{C}$ (June-July), the maximum temperature is $35{ }^{\circ} \mathrm{C}$ (August to December), and the mean air temperature is $22.6{ }^{\circ} \mathrm{C}$. In 


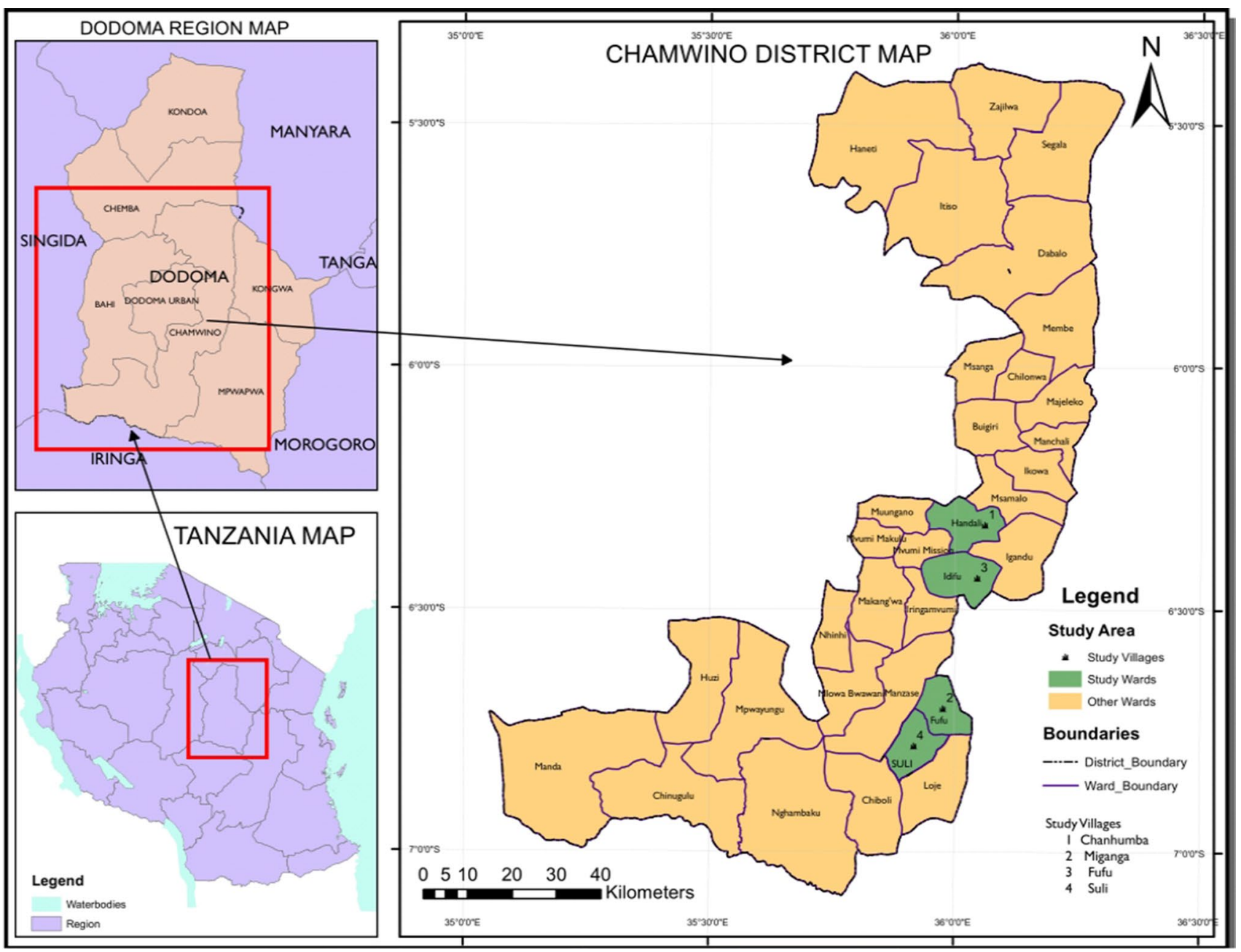

Fig. 1 Map of Chamwino District showing study villages

addition, the mean annual rainfall is $500 \mathrm{~mm}$, and about $85 \%$ of this falls between December and March (Mtupile and Liwenga 2017). One needs to understand the Aridity Index (AI) in order to be certain whether or not Chamwino experiences water shortage. Aridity Index is an indicator of degree of dryness. Some authors define it as a ratio of annual potential evapotranspiration $\left(\mathrm{ET}_{\mathrm{o}}\right)$ to annual precipitation (AP) (Li et al. 2017; Greve et al. 2019), mathematically expressed as:

$\mathrm{AI}=\frac{\mathrm{ET}_{\mathrm{o}}}{\mathrm{AP}}$

where: $\mathrm{AI}=$ Aridity Index; $\mathrm{ET}_{\mathrm{o}}=$ annual potential evapotranspiration, and $\mathrm{AP}=$ annual precipitation.

Others like Sahin (2012) and Gamo et al. (2013) consider AI as a ratio of annual precipitation to annual potential evapotranspiration. This definition basically denotes wetness index, and it is not adopted in this study.
Calculating the value of $\mathrm{AI}$ requires that $\mathrm{ET}_{\mathrm{o}}$ should be known, which is calculated differently in the literature based on data requirement and accessibility. The required parameters, according to Sahin (2012), Zhang et al. (2015) and Greve et al. (2019), include air temperature, net radiation, surface wind speed, vapour pressure deficit, daily free water, atmospheric pressure, water surface temperature and relative humidity. With that, the same authors classify five methods to calculate $\mathrm{ET}_{\mathrm{o}}$. The methods include temperature-based method, radiation-based method, pan-based method, combination model, and Romanenko model. This study adopted the Romanenko model as used by Sahin (2012). The method is practical and requires only mean air temperature and relative humidity, which are easily accessible in dry environments including Chamwino District. The model expresses $\mathrm{ET}_{\mathrm{o}}$ as:

$\mathrm{ET}_{\mathrm{o}}=0.0018\left(25+T_{\mathrm{a}}\right)^{2}\left(100-R_{\mathrm{h}}\right)$ 
where $T_{\mathrm{a}}=$ mean air temperature in ${ }^{\circ} \mathrm{C}$ and $R_{\mathrm{h}}=$ mean annual relative humidity in percent. Considering parameters for Chamwino District, which are $T_{\mathrm{a}}=22.6{ }^{\circ} \mathrm{C}$ and $R_{\mathrm{h}}=60 \%$, and substituting the values into Eq. 2 , the value of ETo $=163.13 \mathrm{~mm}$ per year. Considering $\mathrm{AP}=500 \mathrm{~mm}$ per year, and substituting the values into Eq. 1, it gives $\mathrm{AI}=0.33$. According to the literature including Tsakiris and Vangelis (2005) and Sahin (2012), the value of AI in semi-arid environment falls in a range of $0.20 \leq \mathrm{AI}<0.50$. Therefore, Chamwino District falls under semi-arid environment and so experiences water shortage for different uses including domestic use.

Chamwino covers an area of 8056 square kilometres, and by 2012 it had a population of 330,543 that grew at $2.1 \%$ annually. Using a population projection model presented in the literature including Carmichael (2016) and George et al. (2004), we project the population in the district as follows:

$P_{\mathrm{p}}=P_{\mathrm{t}}+(1+r) n$

where $P_{\mathrm{p}}=$ population in the target year; $P_{\mathrm{t}}=$ population in the launch year; $r=$ annual population growth rate, and $n=$ difference between censured year, which is 2012 in this case, and projected year, which is 2020. Substituting the values into Eq. 3, the population is expected to be 390,332 by the year 2020. Population information is critical when planning for, among others, water supply and sanitation in Chamwino and elsewhere. The district was selected for this study because of the presence of community-based water projects funded by the government and non-governmental organizations (NGOs) (URT 2014b).

\section{Research design, sampling and data collection techniques}

The study employed a sequential exploratory cross-sectional research design that allows data collection at a single point in time, and it is the most appropriate for sample descriptive interpretations as well as determination of relationships between and among variables (Babbie 2007). Time limit and resource available for data collection led to the adoption of cross-sectional research design in this study (Casley and Kumar 1988). The study population was water users in the governmental and NGOs community-based water projects. The sampling procedures involved purposive selection of four villages with community-based water projects and where participatory arrangements were practised. The villages involved are shown in Fig. 1.

In each village, a sub-sample of 30 households was randomly selected making a total sample size of 120 for the survey. We interviewed either the household head, the spouse or any other adult person at the household level. The sample size of 120 is adequate and statistically sound because according to Bailey (1994), it is adequate for statistical analysis leading to reasonable conclusions. A minimum subsample size of 30 in each village was considered because the study population was homogeneous composed of households drawing drinking water from community-based water projects. For populations that are homogeneous, a minimum sub-sample of 30 selected randomly is a true representative of the population and it is adequate for statistical data analysis (Kothari 2004; Martinez-Abrain 2014). Combining the homogeneity of the population, and the fact that the study used random sampling technique, which is a rigorous sampling method, the sub-sample of 30 regardless of the village sizes was essential to avoid unnecessary wastage of resources like time and finance that could occur in case proportionate sampling techniques that consider size of each stratum, in this case villages, were adopted.

Data collection methods included survey, focus group discussions (FGDs) and key informant interviews. Quantitative data were collected using a structured questionnaire with closed ended questions. One FGD was conducted in each division making a total of two FGDs. FGDs involved one Village Water Committee and one Community Water Supply Organization (COWSO). In order to get different experiences on project $\mathrm{M} \& \mathrm{E}$, sex and leadership were used to select FGDs participants. Each FGD comprised 8-10 participants. The proportion of women FGDs participants ranged from 3 to 5 in each group. Women were involved in FGDs because, like other African societies, they are responsible to collect water for domestic use in most communities of Tanzania. FGDs and key informant interviews were used to explore information on background of the projects, types of projects existing in the communities, community participation and activities done during project implementation, institutions responsible for daily implementation of the water project, achievements of the project objectives and importance of community participation in achieving project objectives. The key informants were selected based on the fact that they were well informed because of being responsible for daily water project activities. In addition, the survey guided by a questionnaire was used to collect quantitative data on demographic characteristics and the situation of project in the selected villages, level of achievement of project objectives and the extent to which PM\&E is effective in achievement of water projects' objectives.

\section{Data analysis}

Content analysis was used to analyze qualitative data by summarizing field data based on objectives of the study. The quantitative data were analyzed by using Statistical Package for Social Sciences (SPSS) through computing descriptive statistics to obtain frequencies and percentage distribution of the responses. A Summated Index Scale 
was used to measure the extent of achievement of water projects' objectives and the effectiveness of PM\&E in achievement of water projects. The study used 4 statements to measure the extent of achievement of water projects' objectives, while a total of 16 statements were used to measure the extent of effectiveness of PM\&E. Every respondent was asked to respond whether he/she strongly disagreed (1 score), disagreed (2 scores), neutral (3 scores), agreed (4 scores) or strongly agreed (5 scores) on each item of the scale. The median was used as a cutoff point between low, medium and high achievement of water projects objectives and the effectiveness of PM\&E. The scores below the median represented low extent, the median represented medium, and the scores above the median represented high achievement.

The Cronbach's alpha was used to measure reliability or internal consistence of the scale using a formula developed by Lee Cronbach in 1951 and used by different social science researchers including Fami (2000). The basic equation to calculate the Cronbach's alpha value is given as follows:

$\alpha=\frac{K}{K-1}\left(1-\frac{\sum V_{\mathrm{i}}}{V_{\mathrm{t}}}\right)$

where: $\alpha=$ alpha, $K=$ number of questions, $V_{\mathrm{i}}=$ variance of scores on each question, $V_{\mathrm{t}}=$ total variance of overall scores (not percentages on the entire test).

The achievement of water projects' objectives and the effectiveness of PM\&E on achievement of water projects showed internal consistency with a Cronbach's alpha value of 0.860 and 0.958 , respectively. According to George and Mallery (2003), an alpha value of 0.7 and above is acceptable.

The Kruskal Wallis $H$ test was used to test the null hypothesis that there was statistically significant difference between effectiveness of PM\&E on achievement of water projects implemented by the government and NGOs. This is nonparametric statistic useful in determining significant differences for more than two independent groups for ordinal dependent variable (Pallant 2007). Using the Kruskal-Wallis $H$ test, the test statistic is calculated as follows:

$H=\frac{12}{N(N+1)}\left(\sum \frac{R_{\mathrm{i}}}{n_{\mathrm{i}}}\right)-3(N+1)$

where: $H=$ Kruskal-Wallis $\mathrm{H}$ statistic, $N=$ sample size for all groups, $n_{\mathrm{i}}=$ size of an independent sample within group I, $R_{\mathrm{i}}=$ sum of the ranks for the ith sample.

\section{Results and discussion}

\section{Respondents' socio-economic and demographic characteristics}

Table 1 presents respondents' characteristics. The results show that $53.3 \%$ of the respondents were females. This enabled to capture females' views on issues concerning participation in monitoring and supervision of the communitybased water projects. Involving large number of female water users was crucial because they are the ones responsible for collecting water for domestic uses. The results also show that $49.2 \%$ and $50.8 \%$ of the respondents were household heads and spouses, respectively. In addition, $86.7 \%$ of the

Table 1 Respondents' socio-economic characteristics $(n=120)$

\begin{tabular}{|c|c|c|c|c|c|}
\hline Variable & Chanhumba $(n=30)$ & Miganga $(n=30)$ & Fufu $(n=30)$ & Suli $(n=30)$ & Total $(n=120)$ \\
\hline \multicolumn{6}{|l|}{ Sex } \\
\hline Male & $15(50)$ & $12(40)$ & $15(50)$ & $14(46.7)$ & $56(46.7)$ \\
\hline Female & $15(50)$ & $18(60)$ & $15(50)$ & $16(53.3)$ & $64(53.3)$ \\
\hline Total & $30(100)$ & $30(100)$ & $30(100)$ & $30(100)$ & $120(100)$ \\
\hline \multicolumn{6}{|l|}{ Relationship to the household head } \\
\hline Head of household & $16(53.3)$ & $13(43.3)$ & $17(56.7)$ & $13(43.3)$ & $59(49.2)$ \\
\hline Spouse & $14(46.7)$ & $17(56.7)$ & $13(43.3)$ & $17(56.7)$ & $61(50.8)$ \\
\hline Total & $30(100)$ & $30(100)$ & $30(100)$ & $30(100)$ & $120(100)$ \\
\hline \multicolumn{6}{|l|}{ Main source of income } \\
\hline Farming & $27(90)$ & 28 (93.3) & $27(90)$ & $22(73.3)$ & 104 (86.7) \\
\hline Livestock keeping & $1(3.3)$ & $1(3)$ & $0(0)$ & $6(20)$ & $8(6.7)$ \\
\hline Small-scale business & $1(3.3)$ & $0(0.0)$ & $3(10.0)$ & $0(0.0)$ & $4(3.3)$ \\
\hline Employee in the public sector & $1(3.3)$ & $1(3.3)$ & $0(0.0)$ & $2(6.7)$ & $4(3.3)$ \\
\hline Total & $30(100)$ & $30(100)$ & $30(100)$ & $30(100)$ & $120(100)$ \\
\hline
\end{tabular}

Note Numbers in brackets are percentages 
Table 2 Respondents' marital status and education level $(n=120)$

\begin{tabular}{|c|c|c|c|c|c|}
\hline Variable & Chanhumba $(n=30)$ & Miganga $(n=30)$ & Fufu $(n=30)$ & Suli $(n=30)$ & Total $(n=120)$ \\
\hline \multicolumn{6}{|l|}{ Marital status } \\
\hline Married & $28(93.3)$ & $29(96.7)$ & $27(90)$ & $29(96.7)$ & $113(96.7)$ \\
\hline Single & $1(3.3)$ & $0(0)$ & $1(3.3)$ & $0(0)$ & $2(1.7)$ \\
\hline Widower & $1(3.3)$ & $1(3.3)$ & $2(6.7)$ & $1(3.3)$ & $5(4.2)$ \\
\hline Total & $30(100)$ & $30(100)$ & $30(100)$ & $30(100)$ & $120(100)$ \\
\hline \multicolumn{6}{|l|}{ Education level } \\
\hline No formal education & $0(0)$ & $1(3.3)$ & $2(6.7)$ & $0(0)$ & $3(2.5)$ \\
\hline Primary education & $26(86.7)$ & $27(90.0)$ & $23(76.7)$ & $28(93.3)$ & $104(86.7)$ \\
\hline Secondary education & $3(10.0)$ & $1(3.3)$ & $5(16.7)$ & $2(6.7)$ & $11(9.2)$ \\
\hline Tertiary education & $1(3.3)$ & $1(3.3)$ & $0(0.0)$ & $0(0)$ & $2(1.7)$ \\
\hline Total & 30 (100) & $30(100)$ & $30(100)$ & 30 (100) & $120(100)$ \\
\hline
\end{tabular}

Note Numbers in brackets are percentages

Table 3 Descriptive statistics for respondents' age and household size $(n=120)$

\begin{tabular}{lllll}
\hline Category & Minimum & Maximum & Mean & Std. deviation \\
\hline $\begin{array}{c}\text { Actual age of } \\
\text { respondent }\end{array}$ & 25 & 60 & 38.41 & 7.672 \\
$\begin{array}{c}\text { Actual number of } \\
\text { household }\end{array}$ & 2 & 10 & 5.09 & 1.561 \\
\hline
\end{tabular}

respondents depended on farming activities for their livelihoods. About respondents' marital status, 96.7\% were married (Table 2). With regard to the respondents' education level, $86.7 \%$ held primary education. This implies that majority acquired basic primary education, which is critical for development at a household and national level at large.

The mean age of the respondents was 38 years. This indicates that majority of the respondents were young adults who are potential workforce to participate in socio-economic development activities including working in the communitybased water projects. In addition, the mean number of persons per household was 5.09 (Table 3). This is above 4.9 persons reported at a national level in Tanzania (URT 2014b).
The belief that children are a source of labour at a household level is among the reasons that contribute to large household size in Tanzania and elsewhere in Africa.

\section{Achievement of water projects' objectives}

The community-based water projects had four objectives as shown in Table 4. The responses for columns of agree and strongly agree for the governmental and non-governmental funded projects show that community-based water projects achieved objectives on functionality of water points, increasing water availability and reducing time spent by women and girls to collect water for domestic use in the villages. Qualitative data also showed increasing water availability compared to the situation before establishment of the community-based water projects.

The results also show that the governmental and nongovernmental funded water projects did not achieve the objective on building capacity of the local communities to manage community-based water projects (Table 4). The lack of capacity among the local communities to manage community-based water projects can jeopardize project

Table 4 Degree of achievement of water projects' objectives

\begin{tabular}{|c|c|c|c|c|c|c|}
\hline Objectives & Project & Strongly disagree & Disagree & Neutral & Agree & Strongly agree \\
\hline \multirow{2}{*}{$\begin{array}{l}\text { Extent of achievement of capacity building of local } \\
\text { communities to manage water projects }\end{array}$} & Government & $32(54.2)$ & $19(32.2)$ & $3(5.1)$ & $4(6.8)$ & $1(1.7)$ \\
\hline & Non-governmental & $7(11.5)$ & $31(50.8)$ & $3(4.9)$ & $18(29.5)$ & $2(3.3)$ \\
\hline \multirow[t]{2}{*}{ Extent of achievement of functionality of water points } & Government & $8(13.6)$ & $18(30.5)$ & $3(5.1)$ & $29(49.2)$ & $1(1.7)$ \\
\hline & Non-governmental & $17(14.2)$ & $39(32.5)$ & $3(2.5)$ & $58(48.3)$ & $3(2.5)$ \\
\hline \multirow[t]{2}{*}{ Extent of achievement of increasing water availability } & Government & $0(0.0)$ & $25(42.4)$ & $3(5.1)$ & $30(50.8)$ & $1(1.7)$ \\
\hline & Non-governmental & $0(0.0)$ & $6(9.8)$ & $4(6.6)$ & 48 (78.7) & $3(4.9)$ \\
\hline \multirow{2}{*}{$\begin{array}{l}\text { Extent of achievement in reducing time spent by } \\
\text { women and girls to collect water for domestic use }\end{array}$} & Government & $0(0.0)$ & $15(25.4)$ & $3(5.1)$ & 11 (18.6) & $30(50.8)$ \\
\hline & Non-governmental & $0(0.0)$ & $2(3.3)$ & $0(0.0)$ & $18(29.5)$ & $41(67.2)$ \\
\hline
\end{tabular}

Note Numbers in brackets are percentages 
Fig. 2 Overall achievement of water projects' objectives

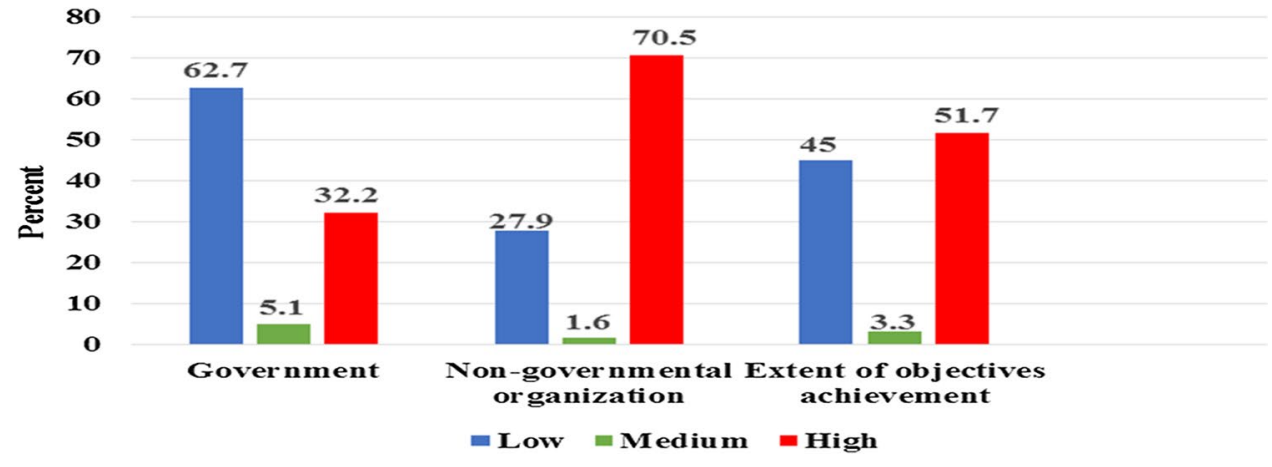

sustainability. The results also imply that the achievement differed by project objectives. The overall achievement of community-based water projects' objectives is shown in Fig. 2. Clearly, 51.7\% of the respondents showed high achievement of community-based water projects' objectives. The governmental and non-governmental projects differed in achieving the objectives. Non-governmental projects showed higher achievements relative to the government projects (Fig. 2).

Although the objective on capacity building of the communities was not achieved as expected, the rest three objectives were achieved. Thus, the results of this study agree with the government and other stakeholders' efforts in improving access to clean and safe water to the Tanzanian population. The Government of Tanzania reformed the water sector by among other things, implementing the Water Sector Development Programme in three phases of five-year each since 2006, guided by the National Water Policy (NAWAPO) of 2002. The programme focuses on water resources management, rural water supply, urban water supply, and institutional development and capacity building through decentralization approach (Lein and Tagseth 2009; URT 2014a; WB 2018). For sound, holistic and sustainable water management, the country has adopted three models of water management as discussed by Lein and Tagseth (2009). They include the 'state centred model' whose principal agents include planners and experts; the "community-based model' whose principal agents include the communities, civil society and water users associations, and the 'marketbased model' that proclaim access to water through purchase of a right in a market and mobilize resources through water fees and private investment.

\section{Effectiveness of PM\&E on achievement of water projects' objectives}

Table 5 presents data on effectiveness of PM\&E on capacity building of the local communities to manage communitybased water projects. Overall, the columns for disagree and strongly disagree for the government projects show that activities like meetings to receive feedback about status of water project implementation, making decisions on issues related to water projects, involvement in paying water fees and involvement in repair of pumps were not effective in terms of building capacity of the local communities to manage community-based water projects. During key informant interviews in Miganga Village, a key informant reported that:

we appreciate the government's commitment in providing water services in our village. But we depend

Table 5 Effectiveness of PM\&E on capacity building of local communities to manage community-based water projects

\begin{tabular}{|c|c|c|c|c|c|c|}
\hline Statement & Project & Strongly disagree & Disagree & Neutral & Agree & Strongly agree \\
\hline \multirow{2}{*}{$\begin{array}{l}\text { Involvement in meeting to receive feedback about status } \\
\text { of water project implementation has created awareness } \\
\text { on water management }\end{array}$} & & & & & & \\
\hline & Non-governmental & $10(16.4)$ & $22(36.1)$ & $3(4.9)$ & $13(21.3)$ & $13(21.3)$ \\
\hline \multirow{2}{*}{$\begin{array}{l}\text { Involvement in meetings to make decisions on issues } \\
\text { related to water project enhanced awareness capacity in } \\
\text { water management }\end{array}$} & Government & $6(10.2)$ & $31(52.2)$ & $2(3.4)$ & $19(32.2)$ & $1(1.7)$ \\
\hline & Non-governmental & $15(24.6)$ & $7(11.5)$ & $5(8.2)$ & $32(52.5)$ & $2(3.3)$ \\
\hline \multirow{2}{*}{$\begin{array}{l}\text { Involvement in paying water fees sensitizes strongly on } \\
\text { managing water projects }\end{array}$} & Government & $31(52.5)$ & $4(6.8)$ & $1(1.7)$ & $8(13.6)$ & $15(25.4)$ \\
\hline & Non-governmental & $8(13.1)$ & $6(9.8)$ & $3(4.9)$ & $41(67.2)$ & $3(4.9)$ \\
\hline \multirow{2}{*}{$\begin{array}{l}\text { Involvement in repair of water pumps improved partici- } \\
\text { pation on water project }\end{array}$} & Government & $6(10.2)$ & $30(50.8)$ & $1(1.7)$ & $7(11.9)$ & $15(25.4)$ \\
\hline & Non-governmental & $13(21.3)$ & $4(6.6)$ & $4(6.6)$ & $34(55.7)$ & $6(9.8)$ \\
\hline
\end{tabular}

Note Numbers in brackets are percentages 
almost everything on them in terms of managing water project.

Thus, communities believed that the government and other stakeholders were responsible to ensure that people in the villages have access to water for domestic use. Reading through the WSDP document, it is clear that water users associations have been constituted at the community level in some areas in the country. However, the practical implementation of the institutional development and capacity building component of the WSDP focuses more at the national and basin levels, compared to the community level. The interventions, among others, include construction of offices and procurement of materials necessary for water resource and quality improvement. Others include creation of boards, constituting catchments water committees and district facilitation teams. This implies that an enabling environment for PM\&E implementation is already in place following the government's efforts that can be seen in the NAWAPO, different programmes and the water Acts. However, in order to make PM\&E more effective emphasis should be on strengthening capacity of the local communities, water users associations and individual users so that they become part of the team managing community-based water projects.

On non-governmental funded water projects, more than $50 \%$ of the respondents in agree and strongly agree columns
(Table 5) showed that involvement in meetings to make decisions on issues related to water projects, involvement in paying water fees and involvement in repair of pumps were effective in achieving capacity building of local communities to manage community-based water projects. Figure 3 shows an overall effectiveness of PM\&E in building capacity of the local communities to manage community-based water projects. Clearly, $50.8 \%$ of the respondents showed high effectiveness of PM\&E. This is attributed to the efforts of the non-governmental water projects that constantly gave feedback to the local communities. In addition to adopting PM\&E, NGOs also adopted the 'market-based model' of charging water fees to mobilize resources. Generally, PM\&E enhances management of water projects through community members. This is important because the challenges affecting water projects can be solved by the community members at that level (Farrelly and Brown 2011). The use of the 'community-based' in combination with the 'market-based' model, as reported by Lein and Tagseth (2009), makes water resource management holistic and sustainable.

Based on the columns for agree and strongly agree for both projects, involvement in meetings to receive feedback about the project from implementers, paying water fees and involvement in repairing of water pumps were effective in terms of making water points functional (Table 6). These results are in line with the existing literature like Anthonj
Fig. 3 Effectiveness of PM\&E in achieving capacity building of local communities to manage community-based water projects

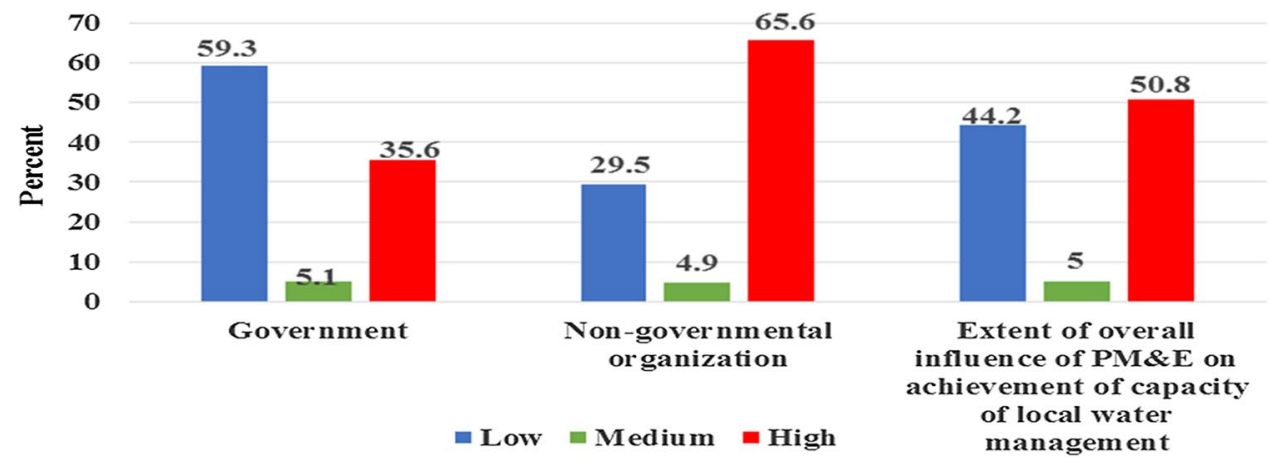

Table 6 Effectiveness of PM\&E in ensuring functionality of water points

\begin{tabular}{|c|c|c|c|c|c|c|}
\hline Statement & Project & Strongly disagree & Disagree & Neutral & Agree & Strongly agree \\
\hline \multirow{2}{*}{$\begin{array}{l}\text { Involvement in meeting to receive feedback about the } \\
\text { project from implementers has created awareness on } \\
\text { how to improve function of water project }\end{array}$} & Government & & & & $42(71.2)$ & $5(8.5)$ \\
\hline & Non-governmental & $5(8.2)$ & $7(11.5)$ & $0(0.0)$ & $46(75.4)$ & $3(4.9)$ \\
\hline \multirow{2}{*}{$\begin{array}{l}\text { Involvement in meeting to make decisions on issues } \\
\text { related to project enhanced functionality of water } \\
\text { projects }\end{array}$} & Government & $6(10.2)$ & $42(71.2)$ & $5(8.5)$ & $5(8.5)$ & $1(1.7)$ \\
\hline & Non-governmental & $2(3.3)$ & $24(39.3)$ & $2(3.3)$ & $26(42.6)$ & 7 (11.5) \\
\hline \multirow{2}{*}{$\begin{array}{l}\text { Involvement in paying water fees sensitizes strongly on } \\
\text { promoting functionality of water projects }\end{array}$} & Government & $10(16.9)$ & $19(32.2)$ & $1(1.7)$ & $25(42.4)$ & $4(6.8)$ \\
\hline & Non-governmental & $5(8.2)$ & $4(6.6)$ & $0(0.0)$ & $27(44.3)$ & $25(41.0)$ \\
\hline \multirow{2}{*}{$\begin{array}{l}\text { Involvement in to repairing of water pumps has led to } \\
\text { functionality of water projects }\end{array}$} & Government & $4(6.8)$ & $19(32.2)$ & $10(16.9)$ & $25(42.4)$ & $1(1.7)$ \\
\hline & Non-governmental & $11(18)$ & $6(9.8)$ & $0(0.0)$ & $24(39.3)$ & $20(32.8)$ \\
\hline
\end{tabular}

Note Numbers in brackets are percentages 
et al. (2018) who reported that community involvement in Ethiopia in water payment and fees collection, maintenance of water pumps and managing water points is one of the factors associated with ensuring water point functionality. This implies that water points managed by the local communities are likely to be functional than those managed by the outsiders. This emphasizes participation of the local communities particularly on issues concerning their livelihoods including water for domestic use.

Overall PM\&E was effective in ensuring functionality of water points (Fig. 4). About 53\% of the respondents showed high effectiveness of PM\&E. This shows that PM\&E showed high influence of ensuring functionality of the water points. Non-governmental community-based water projects were more effective than government funded community-based water projects due to their transparency. This is supported by Gudaga et al. (2018) who showed effectiveness of groundwater governance structures, and or actors in the southern highlands of Tanzania because of transparency and accountability of the actors on issues related to repairs of the water points.

The results also show that PM\&E enabled water availability through involvement of the local communities in meetings to receive feedback about status of water project implementation, making decisions on issues related to water projects, paying water fees and repairing water pumps in non-governmental projects (Table 7). This is attributed to adoption of project management practices in most of the development projects funded by non-governmental organizations including community-based water projects (Golini et al. 2015). Based on columns of strongly disagree and disagree for government project, 50.9\% and $74.6 \%$ of the respondents reported that involvement in meeting to receive feedback about status of water project and involvement of the local communities in making decisions on issues related to water project were not effective in achieving water availability. This is in line with information provided during FGDs that although sometimes beneficiaries were involved in meetings concerning water projects, the final decisions were largely made at a district level. As reported by Tan et al. (2012), the results of this article imply poor effectiveness of PM\&E in involving the local communities in decision making in the governmental relative to non-governmental funded projects. This also implies that participatory approaches in making decisions in community-based water projects were not practised effectively, especially in the government projects.
Fig. 4 Effectiveness of PM\&E in ensuring functionality of water points

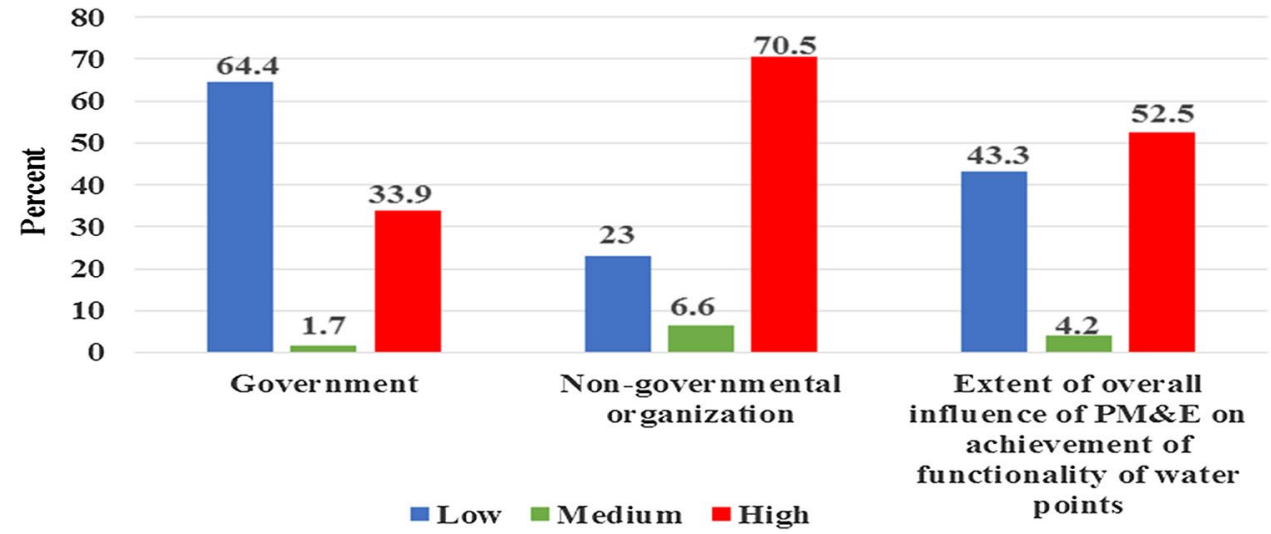

Table 7 Effectiveness of PM\&E in ensuring water availability

\begin{tabular}{|c|c|c|c|c|c|c|}
\hline Statement & Project & Strongly disagree & Disagree & Neutral & Agree & Strongly agree \\
\hline \multirow{2}{*}{$\begin{array}{l}\text { Involvement in meeting to receive feedback about status } \\
\text { of water project implementation has promoted aware- } \\
\text { ness on ensuring water availability }\end{array}$} & Government & $5(8.5)$ & $25(42.4)$ & $0(0.0)$ & $14(23.70)$ & $15(25.4)$ \\
\hline & Non-governmental & $6(9.8)$ & $2(3.3)$ & $3(4.9)$ & $46(75.4)$ & $4(6.6)$ \\
\hline \multirow{2}{*}{$\begin{array}{l}\text { Involvement in meeting to make decisions on issues } \\
\text { related to project enhanced water availability }\end{array}$} & Government & $5(8.5)$ & $39(66.1)$ & $0(0.0)$ & $14(23.7)$ & $1(1.7)$ \\
\hline & Non-governmental & $9(14.8)$ & $11(18.0)$ & $0(0.0)$ & $24(39.3)$ & $17(27.9)$ \\
\hline \multirow{2}{*}{$\begin{array}{l}\text { Involvement in paying water fees sensitizes strongly on } \\
\text { ensuring availability of water projects }\end{array}$} & Government & $6(10.2)$ & $11(18.6)$ & $0(0.0)$ & $25(42.4)$ & $17(28.8)$ \\
\hline & Non-governmental & $5(8.2)$ & $1(1.6)$ & $0(0.0)$ & $28(45.9)$ & $27(44.3)$ \\
\hline \multirow{2}{*}{$\begin{array}{l}\text { Involvement in to repairing of water pumps has led to } \\
\text { water availability }\end{array}$} & Government & $6(10.2)$ & $25(42.4)$ & $0(0.0)$ & $11(18.6)$ & $17(28.8)$ \\
\hline & Non-governmental & $9(14.8)$ & $1(1.6)$ & $0(0.0)$ & $16(26.2)$ & $35(57.4)$ \\
\hline
\end{tabular}

Note Numbers in brackets are percentages 
Fig. 5 Effectiveness of PM\&E on achievement of water availability

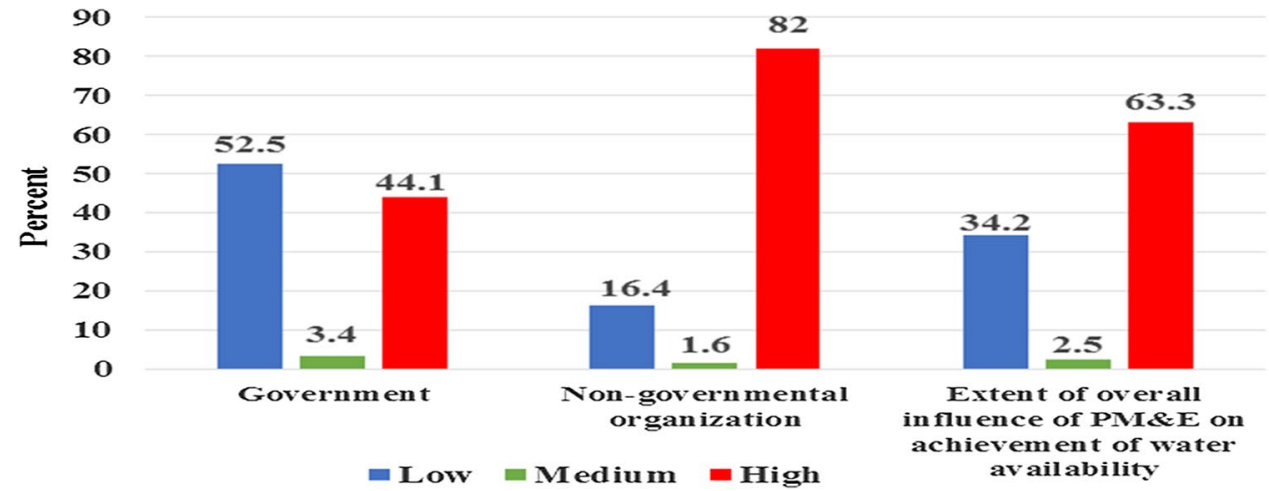

Overall, the extent of effectiveness of PM\&E on achievement of water availability is shown in Fig. 5. It is clear that $63.3 \%$ of the respondents showed high effectiveness of PM\&E in enhancing water availability. This is attributed to non-governmental water projects in which PM\&E was effective relative to governmental funded community-based water projects because of effective participation of the local communities. This is supported by Brown et al. (2012) who argued that local communities' participation in managing water projects ensures security for daily operation of water points. This in turn enhances water availability and sustainability.

The columns for agree and strongly agree for both governmental and non-governmental projects show that involvement of the local communities in meeting to receive feedback on progress of water projects, and making decisions related to water project reduced time used by women and girls to collect water for domestic use (Table 8). However, based on column of strongly disagree and disagree for the government projects, $59.3 \%$ and $70 \%$ of the respondents reported that paying water fees and involvement in repair of pumps did not reduce time used by women and girls to collect water. This is because of dependency on technical support from the government officers in fixing water pump problems, which mostly took long time to be solved. Hence, during a period when communities waited for repair of the water pumps households spent more than $30 \mathrm{~min}$, as recommended by the government, to collect drinking water. These results are in line with Kamara et al. (2017) who reported that $48.9 \%$ of the population in Kahama District in Tanzania accessed drinking water within 30 min during wet season, and $27.3 \%$ during dry season. This implies that rural communities in Tanzania spent more hours to collect drinking water, thus affecting time spent for socio-economic activities.

The overall effectiveness of PM\&E on reducing time used by women and girls to collect water for domestic use is shown in Fig. 6. The results show that $64.2 \%$ of the respondents showed high effectiveness. The effectiveness was higher for non-governmental compared to the governmental water projects. This is because non-governmental funded water projects engaged the local communities effectively in managing water projects. As argued by Artyushevskaya (2014), local communities' participation promotes accountability in ensuring daily operations of water points that allow project sustainability and therefore reduction of time spend by the households to collect water for domestic use.

Table 8 Effectiveness of PM\&E on reducing time used by women and girls to collect water

\begin{tabular}{|c|c|c|c|c|c|c|}
\hline Statement & Project & Strongly disagree & Disagree & Neutral & Agree & Strongly agree \\
\hline \multirow{2}{*}{$\begin{array}{l}\text { Involvement in meeting to receive feedback about status } \\
\text { of water project implementation has created awareness } \\
\text { on reducing time used by women and girls to collect } \\
\text { water }\end{array}$} & Government & $2(3.4)$ & $27(45.8)$ & $0(0.0)$ & $28(47.5)$ & $2(3.4)$ \\
\hline & Non-governmental & $8(13.1)$ & $1(1.6)$ & $0(0.0)$ & $18(29.5)$ & $34(55.7)$ \\
\hline \multirow{2}{*}{$\begin{array}{l}\text { Involvement in meeting to make decisions related to } \\
\text { water project facilitated in reducing time used by } \\
\text { women and girls to collect water }\end{array}$} & Government & $0(0.0)$ & $2(3.4)$ & $2(3.4)$ & $28(47.5)$ & $27(45.8)$ \\
\hline & Non-governmental & $8(13.1)$ & $5(8.2)$ & $0(0.0)$ & $19(31.1)$ & $29(47.5)$ \\
\hline \multirow{2}{*}{$\begin{array}{l}\text { Involvement in paying water fees sensitizes strongly on } \\
\text { reducing time used by women and girls to collect water }\end{array}$} & Government & $31(52.5)$ & $4(6.8)$ & $1(1.7)$ & $8(13.6)$ & $15(25.4)$ \\
\hline & Non-governmental & $6(9.8)$ & $5(8.2)$ & $0(0.0)$ & $18(29.5)$ & $32(52.5)$ \\
\hline \multirow{2}{*}{$\begin{array}{l}\text { Involvement in repair of pumps has led to reducing time } \\
\text { used by women and girls to collect water }\end{array}$} & Government & $6(10.2)$ & $30(50.8)$ & $0(0.0)$ & 7 (11.9) & $15(25.4)$ \\
\hline & Non-governmental & $2(3.4)$ & $5(8.2)$ & $0(0.0)$ & $17(27.9)$ & $37(60.7)$ \\
\hline
\end{tabular}


Fig. 6 Effectiveness of PM\&E on achievement of reducing time used by women and girls to collect water

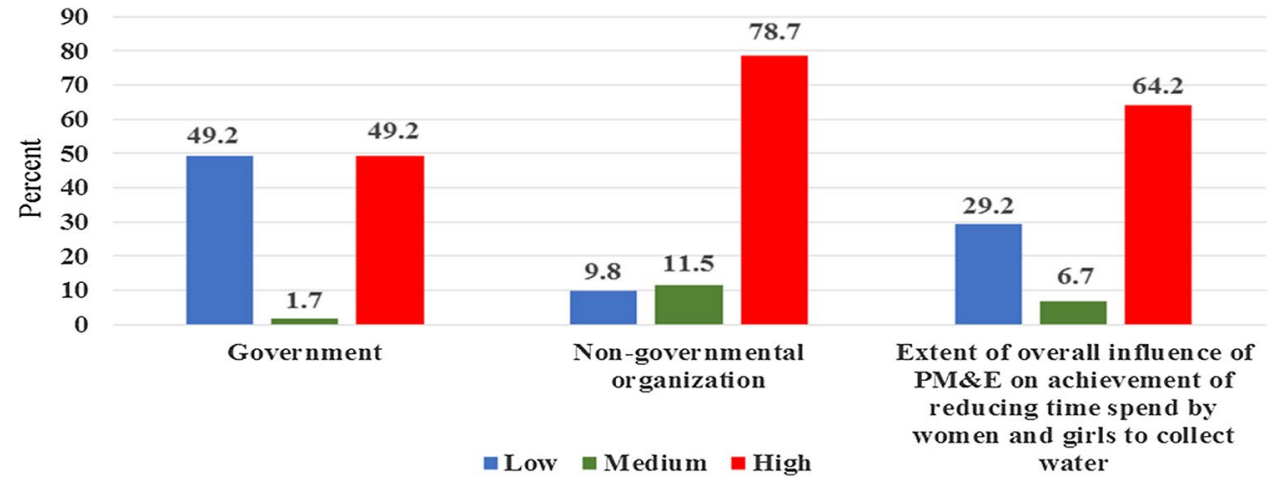

results and discussion, the study concludes that water projects; especially those funded by non-governmental projects achieved targeted objectives in maintaining water points functional; increasing water availability; and reducing time spent by women and girls to collect water for domestic use. However, capacity building, one of the water projects' objectives, was not achieved by the governmental and nongovernmental projects. Secondly, overall, effectiveness of participatory monitoring and evaluation on achievement of community-based water projects was high, more so in non-governmental water projects. The study recommends strengthening of PM\&E for the governmental and nongovernmental funded community-based water projects to improve achievement of the projects. Focus should be on capacity building among local communities so that local communities can manage the projects in the absence of external support. This is a policy issue that needs serious efforts at all levels of the government.

Acknowledgement This article emanates from Masters Dissertation written by Sophia A. Mgoba under supervision of Samwel J. Kabote (Ph. D). The study did not benefit financial support from external funders, but it was privately sponsored by the student. The study acknowledges support received from Local Government Authorities at village and district levels and also from water users during data collection. Water users and local government officers used their precious time in responding to the questions and checklist of this work. We also thank the reviewers because their ideas improved academic rigour of this paper and so it becomes suitable for international readability.

\section{Compliance with ethical standards}

Conflict of interest The authors have declared that they have no any conflict of interest.

Open Access This article is licensed under a Creative Commons Attribution 4.0 International License, which permits use, sharing, adaptation, distribution and reproduction in any medium or format, as long as you give appropriate credit to the original author(s) and the source, provide a link to the Creative Commons licence, and indicate if changes were made. The images or other third party material in this article are included in the article's Creative Commons licence, unless indicated otherwise in a credit line to the material. If material is not included in the article's Creative Commons licence and your intended use is not
The aim of this study was to determine effectiveness of participatory monitoring and evaluation (PM\&E) on achievement of community-based water projects. Based on the

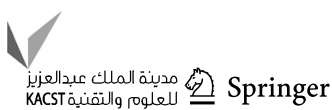


permitted by statutory regulation or exceeds the permitted use, you will need to obtain permission directly from the copyright holder. To view a copy of this licence, visit http://creativecommons.org/licenses/by/4.0/.

\section{References}

Anthonj C, Fleming L, Cronk R, Godfrey S, Ambelu A, Bevan J, Sozzi E, Bartram J (2018) Improving monitoring and water point functionality in rural ethiopia. Water 10(11):1-17

Artyushevskaya NA (2014) The role of women in sustainability of donor-funded rural drinking water supply projects in developing countries: a case study of Tajikistan. State University of New York College of Environmental Science and Forestry

Babbie E (2007) Practice of social research. Oxford University Press, Cape Town, p 92

Bailey KD (1994) Methods of social research. Free Press, New York, p 588

Barbieri M, Ricolfi L, Vitale S, Muteto PV, Nigro A, Sappa G (2018) Assessment of groundwater quality in the buffer zone of Limpopo National Park. Gaza Province, Southern Mozambique, Environ Sci Pollut Res 26(1):62-77

Brown PR, Jacobs B, Leith P (2012) Participatory monitoring and evaluation to aid investment in natural resource manager capacity at a range of scales. Environ Monitoring Assess 184(12):7207-7220

Carmichael G (2016) Fundamentals of demographic analysis: concepts, measures and methods. The Springer Series on Demographic Methods and Population Analysis. Springer, Switzerland

Casley DJ, Kumar K (1988) Collection analysis and use of monitoring and evaluation of data. The International Bank for Reconstruction and Development, Washington DC, p 174

Chebet EB, Kibet JK, Mbui D (2020) The assessment of water quality in river Molo water basin. Kenya Appl Water Sci 10(92):1-10. https://doi.org/10.1007/s13201-020-1173-8

Fami HS (2000) Development of scale to measure the attitude of rural women toward mixed farming. J Human 2(5):25-30

Farrelly M, Brown R (2011) Rethinking urban water management: experimentation as a way forward? Global Environ Change 21(2):721-732

Gamo M, Shinoda M, Maeda T (2013) Classification of arid lands including soil degradation and irrigated areas based on vegetation and aridity indices. Int J Remote Sensing 34(19):6701-6722

George MV, Smith SK, Swanson DA, Tayman J (2004) Population projections. In: Siegel J, Swanson D (eds) The methods and materials of demography. Elsevier Academic Press, San Diego. Retrieved on 7th May, 2020 from https://www.bebr.ufl.edu/sites/default/files /Research\%2520Reports/2004_m_m_projections_.pdf

George C (2020) Why planning a relevant factor in the management of projects? Int J Sci Res 9(2):1543-1547

George D, Mallery P (2003) SPSS for Windows step by step: a simple guide and reference, 4th edn. Allyn and Bacon, Boston, p 123

Golini R, Kalchschmidt M, Landoni P (2015) Adoption of project management practices: impact on international development projects of non-governmental organizations. Int J Project Manage 33(3):650-663

Greve P, Roderick ML, Ukkola AM, Wada Y (2019) The aridity index under global warming. Environ Res Lett 14:2-11

Gudaga JL, Kabote SJ, Tarimo AKPR, Mosha DB, Kashaigili JJ (2018) Effectiveness of groundwater governance structures and institutions in Tanzania. Appl Water Sci 8(2):1-14

Fernandez J, de Palencia A, Perez-Foguet A (2012) Quality and yearround availability of water delivered by improved water points in rural Tanzania: effects on coverage. Water Policy 14(3):509-523
Kabeyi MJB (2019) Evolution of project management, monitoring and evaluation, with historical events and projects that has shaped the development of project management as a profession. Int J Sci Res 8(12):63-79

Kamara JK, Galukande M, Maeda F, Luboga S, Renzaho AMN (2017) Understanding the challenges of improving sanitation and hygiene outcomes in a community-based intervention: a crosssectional study in rural Tanzania. Int J Environ Res Public Health 14(602):1-16

Kanda EK, Muchelule Y, Mamadi S, Ugwu KE, Onwuka EM, Sah B, Jha VK, Gupta S, Pandey VK, Ejem EA, Ibe CC (2016) Factors influencing completion of water projects in Kakamega County, Kenya. Int J Res Manage Sci Technol 4:1-5

Kariuki JG (2014) An exploration of the guiding principles, importance and challenges of monitoring and evaluation of community development projects and programmes. Int J Bus Soc Sci 5(1):140-147

Kifanyi GE, Shayo BMB, Ndambuki JM (2013) Performance of community-based organizations in managing sustainable urban water supply and sanitation projects. Int J Phys Sci 8(30):1558-1569

Kilonzo R, George V (2017) Sustainability of community-based water projects: dynamics of actors' power relations. J Sustain Dev 10(6):79-86

Kothari CR (2004) Research methodology: methods and techniques 2nd revised edition. New Age International (P) Limited Publishers, New Delhi.

Lein H, Tagseth M (2009) Tanzanian water policy reform-between principles and practical applications. Water policy 11:203-220

Li Y, Feng A, Liu W, Ma X, Dong G (2017) Variation of aridity index and the role of climate variables in the Southwest China. Water 9(743):2-14

Mandara CG, Butijn C, Niehof A (2013) Community management and sustainability of rural water facilities in Tanzania. Water Policy 15(S2):79-100

Masanyiwa ZS, Niehof A, Termeer CJ (2015) Users' perspectives on decentralized rural water services in Tanzania. Gender Place Cult 22(7):920-936

Martinez-Abrain A (2014) Is the ' $n=30$ rule of thumb' of ecological field studies reliable? A call for greater attention to the variability in our data. Animal Biodivers Conserv 37(1):95-100

Mfinanga F, Kaswamila A (2014) Challenges in community managed water projects in Dodoma municipality. Int J Mod Soc Sci $3(1): 1-8$

Mthoko H, Khene C (2018) Building theory in ICT4D evaluation: a comprehensive approach to assessing outcome and impact. Inf Technol Dev 24(1):138-164

Mtupile EE, Liwenga ET (2017) Adaptation to climate change and variability by gender in agro-pastoral communities of Tanzania. Int J Environ Agricult Biotechnol 2(4):1651-1659

Pallant J (2007) Statistical package for social science (SPSS) survival manual: a step by step guide to data analysis using SPSS for Windows, 3rd edn. Open University Press, Berkshire, p 335

Radivojevic D, Milicevic D, Blagojevic B (2008) IWA best practice and performance indicators for water utilities in Serbia-case study Pirot. Facta Universitatis 6(1):37-50

Ricolfi L, Barbieri M, Muteto PV, Nigro A., Sappa G, Vitale S (2020) Potential toxic elements in groundwater and their health risk assessment in drinking water of Limpopo National Park, Gaza Province, Southern Mozambique. Environ Geochem Health (2020). https://doi.org/10.1007/s10653-019-00507-z

Saria JA (2012) Water quality in selected shallow wells in Dar es Salaam. Huria J XI:13-24

Sahin S (2012) An aridity index defined by precipitation and specific humidity. J Hydrol 444:199-208. https://doi.org/10.1016/j.jhydr ol.2012.04.019 
Sherman MH, Ford J (2014) Stakeholder engagement in adaptation interventions: an evaluation of projects in developing nations. Clim Policy 14(3):417-441

Tan PL, Bowmer KH, Baldwin C (2012) Continued challenges in the policy and legal framework for collaborative water planning. J Hydrol 47(4):84-91

Tsakiris G, Vangelis H (2005) Establishing a drought index incorporating evapotranspiration. Eur Water 9(3):3-11

URT (2002) National Water Policy. United Republic of Tanzania. https ://www.National Water_policy.pdf, site visited on 01 February, 2019

United Nations (2015) World water development report. United States of America, New York, p 12

URT (2014a) Water sector development programme phase II (2014/2015-2018/2019). Tanzania, Ministry of Water, Dar es Salaam

URT (2014b) Basic demographic and socio-economic profile. http:// tanzania.countrystat.org/fileadmin/user_upload/countrystat_fenix /congo/docs/2012\%2520Tanzania\%2520Population\%2520a nd $\% 2520$ Housing $\% 2520$ Census-Basic $\% 2520$ Demographic $\% 2520$ and $\% 2520$ Socio-Economic\%2520Profile.pdf, site visited on $26 / 01 / 2019$
World Health Organization (2012) Financing water and sanitation in developing countries: the contribution of external aid. Switzerland, Geneva, p 12

World Bank (2010) Analyzing the effects of policy reforms on the poor: an evaluation of the effectiveness of World Bank support to poverty and social impact analyses. World Bank, Washington, DC, p 113

World Bank (2018) Program for results sustainable rural water and sanitation program. World Bank

Zhang K, Pan S, Zhang W, Xu Y, Cao L (2015) Influence of climate change on reference evapotranspiration and aridity index and their temporal-spatial variations in the Yellow River Basin, China from 1961-2012. Quaternary International. Accessed on 13th May, 2020 from https://doi.org/10.1016/j.quaint.2014.12.037

Publisher's Note Springer Nature remains neutral with regard to jurisdictional claims in published maps and institutional affiliations. 